\title{
A SYSTEMATIC REVIEW ON ENHANCED TRANSMISSION AND EFFECTS OF SEVERE ACUTE RESPIRATORY SYNDROME CORONAVIRUS-2: AN INDIAN SCENARIO
}

\author{
KOTTHAPALLI PRASHANTH ${ }^{1}$, SUMANA K ${ }^{1 *}$, SHASHANK M PATIL ${ }^{2}$, RAMITH RAMU ${ }^{2}$
}

${ }^{1}$ Department of Microbiology, School of Life Sciences, JSS Academy of Higher Education and Research, Mysuru, Karnataka, India. ${ }^{2}$ Department of Biotechnology and Bioinformatics, School of Life Sciences, JSS Academy of Higher Education and Research, Mysuru, Karnataka, India. Email: sumana.k@jssuni.edu.in

Received: 28 July 2020, Revised and Accepted: 28 September 2020

\section{ABSTRACT}

The outbreak of severe acute respiratory syndrome coronavirus-2 in Wuhan city of China has taken the entire world to an appalling situation with its detrimental effects on the mankind. Due to the facts on epidemiological and clinical features, it has become evident that the virus comprises several evolutionary factors that enhance its transmissibility and infection. In the absence of specific treatment options, many of the countries have implemented the confinement at varying levels and restrictions to control further infection. In the context, impact of confinement has affected different sectors including economy, social life, environment, health, and education, By virtue of the interrelated mechanism of functioning, these sectors have been ineffective, which, in turn, has affected the normal human lifestyle. This review emphasizes on such social sectors of India, where public life has been facing detrimental effects. It also highlights the facts that are responsible for the enhanced transmission of the virus. The review was initiated with a literature search using PubMed, Google Scholar, EMBASE, and Web of Science, where related keywords were used to collect 259 studies, and 82 of them were finalized based on relevance and information within. It was completed with equal contributions from all the authors in terms of preparing the manuscript.

Keywords: Severe acute respiratory syndrome coronavirus-2, Transmission, Infection, Social sectors, Health, Education, Economy, Environment.

(C) 2020 The Authors. Published by Innovare Academic Sciences Pvt Ltd. This is an open access article under the CC BY license (http://creativecommons. org/licenses/by/4. 0/) DOI: http://dx.doi.org/10.22159/ajpcr.2020.v13i11.39261

\section{INTRODUCTION}

The outbreak of the novel coronavirus disease-2019 (COVID-19) was discovered on December 31, 2019, when China reported few cases like pneumonia infection from an unknown origin in Wuhan city of Hubei Province [1]. Spreading of the disease was so rapid in China and other countries around the world that the World Health Organization (WHO) had to declare it as a pandemic by mid-March 2020 [2]. The causative coronaviruses are large family viruses affecting both avian and mammalian species including humans. These are known to cause infection in the respiratory tract, ranging from common cold to serious illness, and leading to death. Among these, severe acute respiratory syndrome coronavirus-2 (SARS-CoV-2) is a singlestranded ribonucleotide virus with numerous surface proteins known as spikes. Thus, with a crown-like morphology or "corona," the virus has got the term "coronavirus" coined [3]. Being named as SARSCoV-2 by the International Committee on Taxonomy of Viruses, the virus is the second generation of SARS virus. It belongs to the family of $\beta$-coronaviruses and affects humans more in comparison with other viruses. The virus is highly contagious due to recurring mutations that make it more infective than its counterparts [4].

SARS-CoV-2 is a third reported outbreak of major epidemic coronaviruses after Middle East respiratory syndrome (MERS-CoV) and SARS-CoV-1. SARS-CoV-1 was transmitted from zoonotic origin (bat) to the natural host (human) through an intermediate host (civet) during 2003. In 2012, MERS-CoV was possibly able to mutate in the animal reservoirs, where it got transmitted from its natural host (bat) to the intermediate host (camel), prior infecting humans $[4,5]$. Coronaviruses are naturally mild and have no serious effects inside the host, only severities arise when they mutate sufficiently to affect humans through the animal reservoir. Incubation time varies with the viruses, where SARS-CoV-1 is reported to multiply in 2-7 days, MERS-CoV in 2-14 days, and SARS-CoV-2 takes only 2-14 days. The infected subjects are believed to transmit the infection before symptoms develop, thus causing enhanced infection rates [6,7]. The new estimation of the typical SARS-CoV-2 incubation period was 6 days with possible asymptomatic transmission. It is reported to be an airborne virus, which mainly gets transmitted through exchanging aerosols between healthy and infected persons, who show mild pneumonia symptoms. The infected person has the potential of contaminating other healthy persons with a reproductive ratio $\left(R_{0}\right)$ of 2.6. The virus reaches the alveolar cells and hijacks the angiotensin-converting enzyme-2 (ACE2) receptor, which functions to protect the lung tissue against injury. Further, the virus communicates with the receptor using the spike or $S$ proteins, and docks with the host cell. Thus, the virus possesses the advantage of using the cell as a factory, using the cellular components as machinery to invade, replicate, repack, and propagate $[7,8]$.

As July 24, 2020, SARS-CoV-2 cases in India crossed 1.2 million cases having a mortality rate of more than 30,000 deaths, with an average of 500 deaths per day. India's states have been seriously affected by the increasing cases of the pandemic (Fig. 1). The state of Maharashtra tops the list with over 12,000 deaths in 0.34 million cases to date [9]. From January 31,2020 , to July 24,2020 , exponential growth in the number of cases was observed due to an increased incidence pattern where the case fatality rate (CFR) was estimated at $2.3 \%$. CFR is referred to as the total number of deaths to the total number of active cases. But comparing with other countries, the CFR was found to be lesser than United States of America (3.53\%) and Brazil (3.6\%). Most health organizations claim that the CFR should be potentially even lower because of the number of asymptomatic cases associated with the virus $[10,11]$. If asymptomatic cases occur, they should be considered as the reported cases as they may possess the virus in real and may further infect the others. It is also reported that some individuals showed symptoms that anticipated the existence of COVID-19 [11]. Although therapeutic methods such as pharmacotherapy and immunotherapy consisting of several drugs and immunotherapeutic agents have been deployed, none of them are completely able to inhibit the viral load. In addition, the process of vaccine development has also been reported to 


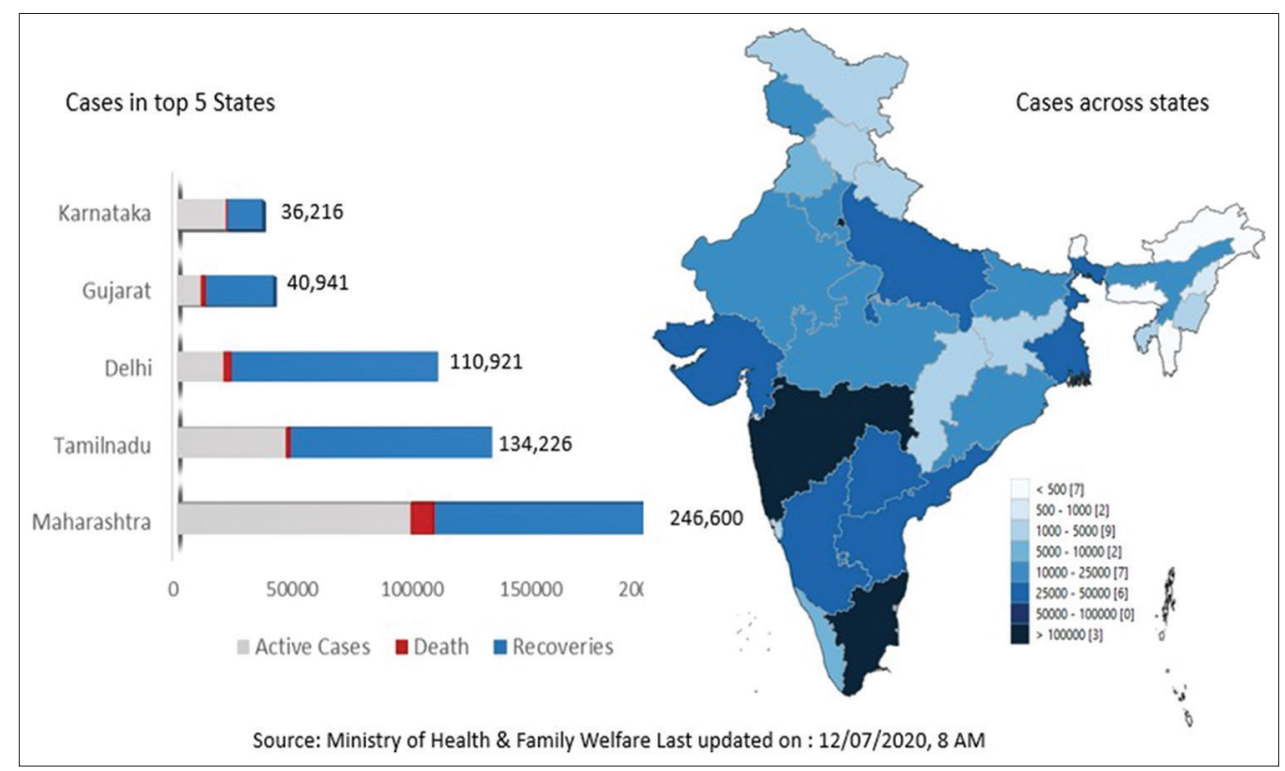

Fig. 1: State wise coronavirus disease-2019 situation in India [14]

be interfered continuously by the evolutionary mechanisms possessed by the virus $[12,13]$. The focal point in this paper is to illustrate the impacts of SARS-CoV-2 on the Indian environment and community and the ways to find to reduce risk factors of the pandemic.

\section{SEARCH STRATEGY AND LITERATURE MANAGEMENT}

The review was planned to highlight the impact of the COVID-19 pandemic on different social sectors of India, including its origin and transmission. As it was designed to deliberate on the aspects related to health, education, economy, and environment, a systematic search was conducted using four major databases. Google Scholar, EMBASE, PubMed, and Web of Science were used to identify published studies related with details about the effects of pandemic on these social sectors. Studies related to enhanced transmission and infection was also given equal importance. The objectives of the review were planned and were independently written by all the authors. The corresponding author was engaged to resolve the conflicting article of interest. For the collection of published studies, we used the key-words such as "SARSCoV-2," “COVID-19," "Viral replication," "Infection," "Transmission," "Evolutionary factors," "Health sector," "Education," "Economy," "Environment," "Industries," "Society," and "Social life." In this manner, individual studies were collected and were further screened according to relevance to suit the requirement. A total of 259 studies were collected and were analyzed for the duplicates and relevant content. Finally, only 82 studies were selected that were able to perfectly fit into the perspective of the review article. The review was completed with equal contributions from all the authors in terms of preparing the manuscript.

\section{STRUCTURE OF THE VIRUS AND GENOMIC ORGANIZATION}

SARS-CoV-2 has a circular shape of $120 \mathrm{~nm}$ diameter, with a viral membrane composed of a lipid bilayer that comprises several transmembrane proteins. The structure has specific structural proteins on the periphery. These include envelope (E), membrane (M), spike $(\mathrm{S})$, and nucleocapsid $(\mathrm{N})$ proteins [15]. The core of the virus includes a positive-sense, single-and stranded RNA of 26-32 kb size bound to few $\mathrm{N}$ proteins. Along with these, there are few accessory proteins coded by open reading frame (ORF) genes, which aid the process of viral replication and stability inside the host. The non-segmented RNA comprises 5'-ORF1ab polyprotein and 3'-polyadenylate tail in the extremities. The organization of the genome includes 2 untranslated regions (UTRs) and is found to be 5'-leader sequence-UTR-replicase-SE-M-N-3'-UTR-polyadenylate tail $[16,17]$. It also includes ORFs variable numbers (6-11). Non-structural proteins (nsps) comprise two-third part of the viral RNA (about $20 \mathrm{~kb}$ ), where the rest is distributed among accessory and structural proteins. The nsps contain two viral proteases including papain-like protease (ppLpro-nsp3) and chymotrypsin-like protease (3CLpro-nsp5). With helicase (nsp13), RNA-dependent RNA polymerase (RdRp-nsp12), and other proteins, these are involved in the biosynthesis of viral proteins [18]. Surface glycoprotein plays a significant role in viral entry into the host cell as it binds the receptor to the surface. There are two subunits present in S glycoprotein (S1 and S2), which gives it a fused appearance. The S1 subunit shares $>70 \%$ similarities with those of human and bat SARS-CoV-2 in terms of an $\mathrm{N}$-terminal mu-phosphatase signal peptide and a receptor binding domain (RBD) [19]. Surface glycoprotein mutations in both subunits induce structural alterations that may further contribute to antigenicity [20]. Further, metagenomic analysis showed that Malayan pangolin SARS-CoV-2-like coronavirus displayed $91.02 \%$ and $90.55 \%$ resemblance at the genomic level to human SARS-CoV-2 and Bat coronavirus (Bat CoV), respectively. This showed that pangolin-CoV was the most directly linked coronavirus to human SARS-CoV-2 after Bat $\mathrm{CoV}$, indicating the possible reservoirs of the virus. This has further raised speculations about the actual origin of the virus [21,22].

\section{FACTORS RESPONSIBLE FOR ENHANCED LETHALITY}

\section{Homologous recombination}

Homologous recombination is believed to be one of the most feasible approaches through which the SARS-CoV-2 is reported to mutate by acquiring the host molecular machinery. Homologous recombination between coronavirus genomes takes place during co-infection in the host cell. SARS-CoV-2 utilizes the transcription regulatory sequence to process homologous recombination using a mechanism close to a template-choice recombination process [17]. The RdRp when anchored to the nascent nucleotide chain, the transfer from a donor to an acceptor template occurs, where both templates are from numerous closely related viruses. The SARS-CoV-2 genome could have experienced a common form of homologous recombination during coinfecting an intermediate host with a closely associated donor coronavirus [23].

\section{Subtypes}

SARS-CoV-2 is reported to have evolved into two main subtypes, termed as " $\mathrm{S}$ " and "L" subtypes. From a recent evaluation it is evident that the "S" type accounts for $30 \%$ infection of SARS CoV-2, whereas "L" accounts for the rest $70 \%$. Symptoms of "S" subtypes are reported to be less severe and less aggressive, and "L" subtype is reported to cause more severe and more aggressive symptoms in the host that has been infected with $[24,25]$. The "S" subtype is believed to be originated from 
a potential zoonotic source and has further evolved into "L" subtypes of SARS CoV-2. These are categorized as such because of the unique single nucleotide polymorphs (SNPs) that exist in the viral genome. A study has revealed that 72 of 103 viral strains (70\%) exhibited a "CT" haplotype (denoted as "L" subtype because of the T28, and 44 SNP found in Leucine codon). The other 29 strains (30\%) showed a "TC" haplotype (denoted as "S" subtype because of the C28, and 144 SNP found in Serine codon) [25].

\section{Rate of transmission}

The transmission rate of SARS CoV-2 depends on two specific variables, reproductive ratio $\left(R_{0}\right)$ and series interval $(S I)$. $R_{0}$ measures the ability of the virus to move from one infected person to another, with the range between 2 and 4 . SI aids in the determination of time taken for a successful infection [26]. Several studies conducted on SARS-CoV-1 suggest that the virus shows the $\mathrm{R}_{0}$ nearly as 3 . Researchers also highlighted the fact that epidemics with $\mathrm{R}_{0}>1$ could make the imposition of quarantine or confinement. Although the $\mathrm{R}_{0}$ value has not yet been predicted in case of SARS-CoV-2, the high rates of mortalities reported around the world indicate the $\mathrm{R}_{0}$ could be more than 3 . The literature also suggests that maintenance of 6 feet distance from individuals could fairly reduce the transmission, hence the infection rate [27].

\section{Advancements in viral binding}

The virus is reported to use $S$ protein as the principal interacting protein to adsorb on host cell using receptors present on the cell membrane. Subsequently, $S$ protein gets cleaved into $S_{1}$ and $S_{2}$ by host cell proteases, like trans-membrane protease serine 2 along with lysosomal proteases known as cathepsins. Furthermore, human airway trypsin-like protease, furin, and trypsin are reported to be involved. $S_{1}$ subunit binds with the surface receptors, whereas $\mathrm{S}_{2}$ is found to mediate the fusion of viral and host membrane [28]. $\mathrm{S}_{1}$ has an RBD that recognizes ACE2 as its receptor [29]. RBD switches between immune evasion and receptor binding. At the binding site, SARS-CoV-2 RBD has is reported to have better flexibility than that of SARS-CoV-1, which means SARS-CoV-2 must resolve the higher instability to bind ACE2 and is more prone to human infection than SARS-CoV-1 [30]. Recent protein modeling studies suggest the stronger binding affinity of SARS-CoV-2 toward human ACE2 receptors [31]. ACE2 is substantially found in type II alveolar cells, extra-pulmonary tissues of the heart, lungs, and endothelium of the intestine [32]. SARS-CoV-2-ACE2 binding contributes to severe lung injury. These features of the emergence of SARS-CoV-2 contribute to its increasing prevalence with severe symptoms and mortality rates [33].

\section{Invasion and replication}

On the entry through the host respiratory tract, the viral membrane fuses with the host cell membrane facilitating the entry of viral RNA into the host cell. This phenomenon makes the individual infected with the virus while being asymptomatic [34]. The SARS-CoV-2 RNA functions as an mRNA template to synthesize the polyprotein replicase 1a (pp1a) and 1ab (pp1ab). Further, non-structural proteins including RdRp, helicase and nsp3, 4, and 6 are produced through proteolytic cleavage of pp1a and pp1ab. These nsps account for anchoring the replication/transcription complex to endoplasmic reticulum (ER) membrane, forming double membrane vesicles [35]. As a result of this localization, RdRp and helicase together endeavors to produce subgenomic RNAs which, in turn, synthesize structural and accessory in the subsequent translation. Once the process gets completed, surface proteins $\mathrm{S}, \mathrm{M}$, and $\mathrm{E}$ gets adhered in $\mathrm{ER}$, from where they get moved to the endoplasmic reticulum-Golgi intermediate compartment complex (ERGIC). Meanwhile, N proteins connect with the viral RNA in cytoplasm to synthesize nucleocapsid. With the completed final virion assembly in the ERGIC, mature and processed virions get released through smoothwall vesicles by exocytosis [36-38].

\section{ADVANCEMENTS IN MODES OF TRANSMISSION}

Coronaviruses mainly cause enteric or respiratory tract infections. When an infected person coughs or sneezes, the air droplets are carried up to the distance up to 6 feet and can land on surfaces that people touch. In general, the virus gets transferred to any asymptomatic person who comes in contact with the infected one. This could be prevented by hand washing and surface sterilization. Avoiding close contact with infected can relatively reduce transmission [39].

\section{Aerosol transmission}

Aerosol transmission can occur when an infected person coughs, sneezes, breaths intensely, or talks loudly with a healthy individual. The virus is expelled from the body and can form bio-aerosols on interacting with the aerosols produced [40]. The particles in a bio-aerosol measure up to $0.3-100 \mu \mathrm{M}$ in diameter. However, the fraction of $1-10 \mu \mathrm{M}$ in the breathable range is of primary concern. Aerosols measure typically 1-5 $\mathrm{mm}$. They spread out from the source of infection in a space of around 1-2 $\mathrm{m}$. The aerosol can travel hundreds or more meters [39]. Super emitters are the ones that, when conversing with each other, scatter these aerosol particles from one to another within a certain distance. Breeding grounds for the infection could be cramped spaces or poorly ventilated indoors. A single person in a room can release enough aerosolized virus over time. Aerosols are smaller in size so that they carry fewer viruses than large droplets. Measures such as wearing masks and social distance will help to minimize aerosol transmission significantly. Ideally avoiding crowded indoors and rooms with circulating ample fresh air with open windows will contribute much more [41]

\section{Fomite transmission}

Indirectly, the virus can remain on some of the surfaces known as fomite surfaces and can spread the virus if an individual touches the surfaces either knowingly or unknowingly. For a certain amount of time the virus has the potential to be on the surfaces, within which it can still infect an individual [42]. For example, the virus can stay active up to $8 \mathrm{~h}$ on aluminum, latex, and copper. Similarly, cardboard (24 h), plastics, stainless steel, cover tops (1-3 day), glass, and wood (5 days) [43]. This mode of infection can also be considered as equally dangerous to aerosol transmission. In addition, there is also a risk of fecal-oral route. The virus also has the potential to transmit from mother to the fetus [40].

\section{IMPACTS ON INDIAN SUBCONTINENT}

The pandemic has severely impacted the entire population and economy of India and the world. At first, the assumption was that only in China would the SARS-CoV-2 pandemic be localized. It later spread through the migration of people all over the world. The unexpected economic burden caused by SARS-CoV-2 is not only disruptive but also spillover as it causes demand and supply disturbances in almost every sphere of human activity [44]. In India, the public response to the pandemic and lock-up was large and best used to reduce the cases. Communications during the pandemic are extremely critical because inadequate communication may contribute to a prolonged spread of the disease. Public health officials have been resolving these issues since the commencement of lockdown. Social connections are essential to human life, but due to the rapid spread of the virus and increase in social distancing steps, these networks have been seriously affected [45]

\section{Economy}

In view of the protective steps and the government's declaration of a national lock-up to control the COVID-19 pandemic, major industrial sectors have not been functional since the end of March 2020. A country's industrial economy elevates with imports and exports that affect the trade, which, in turn, becomes the pavement for a country's economy [46]. These factors have impacted on different types of sectors including aviation, mining, energy, textile manufacturing, vehicle manufacturing, hardware, and sports sectors. In addition, entertainment, event management, and tourism are the other sectors affected under the industrial zone [44]. In general, unavailability of workers, engineers, mechanics, and other officials declined the industrial output, which, in turn, affected the investment. In addition, decrease in the demand for the material also played the role, further dismantling the interconnected network between manufacturers and the customers [47]. Reduced revenue results in less wages leading to 
fewer taxes paid and lack of demand for sales. This resulted in the loss of employees, further leading to a lack of compensation and economical help (health insurance, loans, mutual investments, etc.) [48]. For example, in April 2020, India reported 122 million job losses and then saw 91 million of these recover by June. Relatively higher labor participation and unemployment was seen in the states of Karnataka, Haryana, and Bihar whereas lower level of labor participation and unemployment rate was seen in states of Delhi, Himachal Pradesh, Gujarat, Rajasthan, and Andhra Pradesh. In India, by the month of June 2020, the unemployment rate was increased to 10.99 from 9.86 [49]. The affected categories include small traders and laborers (-91.3\%), entrepreneurs (-18.2), and salaried employees (-17.8) [50]. Compiling household income during the lockdown is expected to begin from September or October of this year 2020. The proportion that said their income was higher than it was a year earlier in April was 9.6\%. This dropped in May to 6.1\%, and then in June to $4.4 \%$. Employment recovery is not at all expressed in expectations about income growth. Interestingly, farmers count has been increase in April $2020(+5.8)$, due to the fact that youth living in cities returned back to the villages to practice farming and agriculture [49].

Usually, different companies, societies, and organizations around the world nearly perished, shadow the capital markets, subsequently global economy [51]. Therefore, investor loss has affected turnaround plans, policy, and business proposals. Investment in the pharmaceutical industry was expected to increase in the time of pandemic [52]. However, the nature of the transmission and elevated risk factors has surely hit the pharmaceutical industry as well, reducing the export of medicines related with non-COVID diseases and disorders. This has also impacted on the manufacturing and supply of standard medical equipment needed for both COVID and non-COVID patients [53,54]. Countries have shut down national borders putting sudden halt to international commerce and trade. Hardware sectors have been relying on foreign countries since decades and have nearly perished due to lack of manufacturing units and production. As per the Society of Indian Automobile Manufacturers Society's survey, overall auto sales fell by $60 \%$ in March as the pandemic escalated. Ministry of Micro, Small, and Medium Enterprises have faced huge losses in the economic crisis. The same has resulted in case of nonbanking financial companies, and the agri-sector. Being a major exporter of agricultural products, the confinement affected Indian farmers, thus reducing the crop output [55]

An overall effect on the goods produced by the establishments was found during the month of April 2020. The world economic market experienced a drastic change with constant share markets crashes. As a result, financial losses have triggered the economic crisis, with possible fall of 13.0-32.0\% global trades and reducing global gross domestic product by $2.0 \%$ [56]. In the same month, the industrial output index for the mining, manufacturing, and energy sectors was $78.3 \%, 45.1 \%$, and $12.6 \%$, respectively. According to the use-based classification, implications found out to be $92.3 \%$ (primary goods), $7.7 \%$ (capital goods), 42\% (intermediate goods), and $21.7 \%$ (infrastructure/ construction goods). In addition, the consumer durables and consumer non-sustainable indices are $5.5 \%$ and $89.4 \%$, respectively. The weight response rate is compiled at $87 \%$ as per the April 2020 rapid estimate [57]. However, these facts could escalate in the time of un-lock situation, and they may drive the country's economy to its old glory.

\section{Social life}

In view of the lockdown and present pandemic situation, most of the economically weaker communities are dependent on daily wages and pose for migration to various places. As a result of confinement, unknowingly they returned to their natives with the risk of getting infected. It has become evident that the world is facing huge repercussions including the human cost of the pandemic, the loss of loved ones, the emotional devastation, and the physical pain of the outbreak. Furthermore, the situation of confinement could result in isolation maximally among children and adolescents [58]. The unknown future influences people's endurance, stressing them to a point beyond imagination. Effects of confinement on individual life are diverse, as they include a sense of fear as well as stress, anxiety, and other mental illnesses. Fear and anxiety over an illness can be debilitating in adults and children and can trigger intense emotions [59]. In addition, case studies conducted on people have reported that increased isolation could trigger psychological aberrations, some of them were even reported the occurrence of diseases such as Alzheimer's and dementia [60]. Increased work pressure on medical staff could trigger the outburst of stress and emotions which disturb a person's mental health for longer period [58]. Social works, psychiatrists, and psychologists have reported that many of their patients showed negative emotions such as depression, indignation, and suicidal thoughts [59,61]. With the lack of physical activity, mental health also gradually fades, and may even permanently affect the person. Therefore, it is evident that strict confinements for longer durations could damage the mental health. To avoid this, confinements with few restrictions could be implemented, aiming for the secured lifestyle.

\section{Environment}

Attempts to limit the COVID-19 transmission by restricting vehicle movements have had an excellent impact on the climate. Waste emissions from industries have reduced to a large degree due to the non-functioning factories. Reduced number of vehicles on the street has resulted in almost zero greenhouse gas emissions and harmful small suspended particles to the atmosphere $[62,63]$. For example, a study evaluated the concentrations of particulate matter (PM) and other gases such as carbon monoxide ( $\mathrm{CO}$ ) and nitrogen dioxide $\left(\mathrm{NO}_{2}\right)$ before and after lockdown in New Delhi. Later, it was revealed that $\mathrm{PM}_{10}$ and $\mathrm{PM}_{2.5}$ concentrations reduced by $50 \%$ compared to pre-lockdown conditions. Similarly, pollutants such as $\mathrm{CO}$ (35\% reduction) and $\mathrm{NO}_{2}(52.68 \%$ reduction) have also been decreased. The study also reported $40 \%-$ $50 \%$ recovery in air quality just after 4 days of lockdown initiation. The national air quality index has observed with $31 \%-54 \%$ reduction around the New Delhi [64]. Due to the lower power demand in manufacturing, use of fossil fuels has been drastically reduced, leaving the ecosystems under tremendous improvements. The amount of pollution in tourist sites has been reduced to a large extent. Aerosol is one of the major contaminants listed by the national and international agencies linked to mortality and morbidity. There was a disparity in aerosol level during lockdown in India which was at its lowest level [65].

A study has reported effects of meteorological factors on COVID-19. In this study, it was revealed that temperature and moisture have no effect on virus transmission and only the government restrictions would be able to control it. In addition, steep decreasing in aerosol concentration and $\mathrm{PM}_{10}, \mathrm{PM}_{2.5}$, and nitrogen monoxide (NO) were reported in major cities of India, including Kolkata, Mumbai, Chennai, Ahmedabad, and Hyderabad. The findings suggest the novel coronavirus is treated as a hidden blessing [66]. Furthermore, there is a dramatic change in the quality of water and increase in the number of Indian rivers such as Ganges, Cauvery, and Yamuna. Due to a lack of industrial affluents to river water and a lockdown scenario in a pandemic situation, the dissolved oxygen (DO) level in the ganga river is above $8 \mathrm{ppm}$ and the biological oxygen demand is below $3 \mathrm{ppm}$, which was around $6.5 \mathrm{ppm}$ and $4 \mathrm{ppm}$ in 2019. Alongside DO, pH, and ammonia levels have also come below the critical limit [67]. Although economic impact on industries has put a large economic burden, the confinement appears to put beneficial effect that allowed the nature to flourish. The confinement situation was inevitable yet it has shown us the path to a clean and healthier environment.

\section{Health}

The advent of SARS-Cov-2 and its subsequent spread has overshadowed all the alerts and has caused an emerging global and economic crisis in public health. In the absence of specific treatment options, only non-pharmaceutical interventions in the medical and public health community could focus on to reduce COVID-19 burden $[68,69]$. Such initiatives are aimed at preventing disease transmission locally and internationally, by banning public gatherings, imposing stay-at- 
home restrictions, closing school and college, ceasing non-essential businesses, imposing face mask usage regulations, creating awareness about home and hospitalized quarantine, and creating confinement zones [70].

India has 25,778 government hospitals and 122 railway hospitals with average of 7.1 lakh beds. There are more than 8000 ventilators in government hospitals and 30,000 in private hospitals that can contribute in fighting the disease. In a developing and populous nation like India, the existing health-care system has been affected with accessibility and affordability challenges. The pandemic will more likely to overwhelm the medical personnel already overburdened. Medical staff is directly bearing the onslaught of the disease and is under tremendous physical and mental stress $[71,72]$. Health and social systems across the globe have been struggling to cope since the emergence of the pandemic. Civilians need to coopertate with them understanding mammoth efforts taken by the personnel. Taking an oath to support the medical staff by civilians has been implemented according to the public health guidelines. Thus, combating COVID-19 with this approach could be a great step. The present situation is already impacting humanitarian, fragile, and under-developed country contexts with health-care systems having diminishing scope. Report from the WHO depicts that one in ten health workers is getting infected with the COVID-19. Thus, population needs to work comprehensively to flatten the curve of transmission as per the initiatives given by the WHO [73].

Despite an inevitable worldwide lockout, there tends to be a much stronger dependence on pharmacists as the first point of contact to satisfy the health-care needs of the nation $[70,74]$. Hospitals around the globe are one of the only areas where public service is held available even during the tight lockdowns. Local pharmacists and their staff have become a critical health-care resource throughout the outbreak; they stay at the center of public safety by representing their customers as primary access points [75]. Like every other sector, the Indian pharmaceutical industry has experienced tremendous transition over the past decade. The role of the medical advisor is also becoming increasingly important, due to the emerging medical science and the competitive environment. With changes in regulatory laws, safety monitoring, and the concept of medical liaisons in India, the function of the medical consultant is continuously changing. It is likely to continue to develop in important areas such as health economics, public and private collaborations, and strategic planning in the coming years [76].

\section{Education}

Most of the nations have agreed to shut down educational institutions such as schools, colleges, and universities due to the ominous infective nature of the pandemic. The crisis encapsulates the policymaker's conundrum between shutting down schools, colleges, and maintaining them open. Several families in different countries have been experiencing the colossal amount of short-term chaos: Schooling in home environment is a daunting task in terms cost, social life, and learning of the children $[77,78]$. However, it is a laudable approach that the Government of India introduced several e-learning platforms for school children (Classes 1-12) such as "Diksha" and "e-Pathshala" applications that comprise audios, videos, and textbooks uploaded by teachers. These applications are designed under the guidance of Central Board of Secondary Education and National Council of Educational Research and Training and can also be used offline. In addition, National Repository of Open Educational Resources is web portal that provides resources to both teachers and students in terms of text, interactive models, a host of science, technology, engineering, and mathematics based games, and other audio-visual content. Further, e-platforms called "Swayam" and "e-PG Pathshala" have been designed to help students in classes 9-12, under graduates, and postgraduates. The portal comprises the contents related to law and management, humanities and social sciences, and engineering. Furthermore, 32 free direct-to-home channels with educational content have been launched under the scheme of "Swayam Prabha." These channels are available in all types of set-top boxes and antenna, which comprise the similar content as "Swayam" and "e-PG Pathshala." Moreover, teachers and evaluators have been using social media and interaction applications such as WhatsApp, YouTube live, Zoom app, Skype, Google Meet, Team Link, and Google classroom. Among them, Zoom app (34.2\%) has been widely used for online classes, whereas WhatsApp has been used for content sharing $(39.4 \%)$ and online evaluation $(40.5 \%)$. With the teaching has moved to online platform, on an untried and unparalleled scale. Student evaluations also shifted to online, with a lot of trial and errors, creating confusion for everyone [79].

The aim is to continue the home education in the expectation that children should not miss too much of the activities. In addition, college education is also under dilemma whether to conduct examinations or to grade the students without it. Despite mammoth efforts to improve digital learning, there have been several problems associated with students. In a study conducted in a state of West Bengal, more than $70 \%$ of the students were involved in e-learning through different platforms, about $32.4 \%$ of students living in rural and remote areas have been facing problems with internet connectivity. As a result, about one-third of the students (36.2\%) did not know about the University Grants Commission committee report regarding academic spheres, which happens to be one of the principal educational reports in India [79]. The global lockdown of educational institutions is expected to cause significant disturbances in learning for students; teaching for the staff; conducting examinations and evaluations; and the cancelation of public qualification assessments or their replacement by an inferior methods $[80,81]$. For example, $54.3 \%$ of the students reported that they were not spending more time in learning due to the confinement and $11.6 \%$ of them reported that half of the syllabus has not been covered. Most of the students (42\%) admitted that they were suffering from anxiety, stress, and depression. Practical sessions for students have been cancelled, which certainly affects the understanding of the concepts by children. Families are fundamental to education and are generally believed to contribute substantially in a child's learning. About $76.7 \%$ of students believed the pandemic have ruined their education and around $75.9 \%$ reported that the pandemic would nearly cause their educational discontinuation [79]. Considering these facts one can denote that, despite the substantial efforts of the government, economic burden prevails on Indian families that cannot afford digital education for their children, therefore, with suboptimal results from online platform of education, it is nearly impossible to give effective education, without opening educational institutions [82].

\section{CONCLUSION}

SARS-CoV-2 has already been proved to be a global threat affecting different sectors of society. In a populous country like India, the enhanced transmission due to recurring mutations in the viral genome could have triggered millions of deaths. However, one should applaud the decision taken by the Government of India to implement the confinement, despite the losses to the national economy. The Indian scenario depicts the role of lockdown both as beneficial and detrimental to these sectors. Although tremendous loss has happened to education and economic sectors, recovery has been observed in recent days. In the vista, pressure has been increasing on health sector since the beginning to reduce the burden. In support of this, many of the studies have reported the null effect of temperature and other meteorological effects on COVID-19, which were the most expected relaxations in India. Furthermore, these studies have reported the importance of Government restriction, referring to the beneficial effects observed in coastal states Kerala and Maharashtra with no such effects from meteorological factors. With this under concern, it is suggestible that COVID-19 can be fought in either ways including the therapeutic approach or the social confinement, till the specific treatment or vaccine available.

\section{ACKNOWLEDGMENTS}

All the authors thank JSS AHER for the support and encouragement. 


\section{AUTHOR'S CONTRIBUTIONS}

Data acquisition: Prashanth Kotthapalli; Concept and design: Sumana $\mathrm{K}$ and Shashank M Patil; Critical revision of manuscript: Ramith Ramu. The review was completed with equal contributions from all the authors in terms of preparing the manuscript.

\section{CONFLICTS OF INTEREST}

The authors declare that there are no conflicts of interest.

FUNDING

Nil.

\section{REFERENCES}

1. Huang C, Wang Y, Li X, Ren L, Zhao J, Hu Y, et al. Clinical features of patients infected with 2019 novel Coronavirus in Wuhan, China. Lancet 2020;395:497-506.

2. World Health Organization. WHO Director-General's Opening Remarks at the Media Briefing on COVID-19; 2020. Available from: https://www.who.int/dg/speeches/detail/who-director-general-sopening-remarks-at-the-media-briefing-on-covid-19---11-march-2020. [Last accessed on $2020 \mathrm{Jul} 22$ ].

3. van Boheemen S, de Graaf M, Lauber C, Bestebroer TM, Raj VS, Zaki AM, et al. Genomic characterization of a newly discovered Coronavirus associated with acute respiratory distress syndrome in humans. mBio 2012;3:473-12

4. Yang P, Wang X. COVID-19: A new challenge for human beings. Cell Mol Immunol 2020;17:555-7.

5. Nadeem MS, Zamzami MA, Choudhry H, Murtaza BN, Kazmi I, Ahmad H, et al. Origin, potential therapeutic targets and treatment for Coronavirus disease (COVID-19). Pathogens 2020;9:307-19.

6. Shereen MA, Suliman K, Abeer K, Nadia B, Rabeea S. COVID-19 infection: Origin, transmission, and characteristics of human Coronaviruses. J Adv Res 2020;24:91-8.

7. Hui DS, Memish ZA, Zumla A. Severe acute respiratory syndrome vs. The Middle East respiratory syndrome. Curr Opin Pulm Med 2014;20:233-24.

8. Kumari VC, Patil SM, Shirahatti PS, Sujay S, Tejaswini M, Ranganatha LV, et al. The current status and perspectives for the emerging pandemic: COVID-19. Int J Pharm Pharm Sci 2012;12:1-12.

9. Chen Y, Liu Q, Guo D. Emerging Coronaviruses: Genome structure, replication, and pathogenesis. J Med Virol 2020;92:418-23.

10. European Centre for Disease Prevention and Control. Novel Coronavirus Disease 2019 (COVID-19) Pandemic: Increased Transmission in the EU/EEA and the UK. Stockholm: ECDC; 2020. Available from: https:// www.ecdc.europa.eu/sites/default/files/documents/RRA-sixth-updateOutbreak-of-novel-coronavirus-disease-2019-Covid-19.pdf. [Last accessed on $2020 \mathrm{Jul} 22]$.

11. Mahalmani VM, Mahendru D, Semwal A, Kaur S, Kaur H, Sarma P, et al. COVID-19 pandemic: A review based on current evidence. Indian J Pharmacol 2020;52:117-9.

12. Patil SM, Kumari VC, Shirahatti PS, Sujay S, Tejaswini M, Ranganath LV, et al. COVID-19 infection: The prospects of pharmacotherapy. Int J Health Allied Sci 2020;9:111-3.

13. Sasmi MB, Jose M, Kuttichira P. Current therapeutic options for Coronavirus disease-2019-a pharmacological review. Asian J Pharm Clin Res 2020;13:42-50.

14. World Health Organization. Novel Coronavirus Disease (COVID-19) Situation Update Report No. 24; 2020. Available from: https://www. who.int/docs/default-source/wrindia/situation-report/india-situationreport-24.pdf?sfvrsn=dd1c8402_2. [Last accessed on 2020 Jul 14].

15. Mousavizadeh L, Ghasemi S, Genotype and phenotype of COVID-19: Their roles in pathogenesis. J Microbiol Immunol Infect 2020;20:30082-7.

16. Smith EC, Mark RD. Coronaviruses as DNA wannabes: A new model for the regulation of RNA virus replication fidelity. PLoS Pathog 2013:9:e1003760.

17. Denison MR, Graham RL, Donaldson EF, Eckerle LD, Baric RS. Coronaviruses: An RNA proofreading machine regulates replication fidelity and diversity. RNA Biol 2011;8:270-9.

18. Khailany RA, Safdar M, Ozaslan M. Genomic characterization of a novel SARS-CoV-2. Gene Rep 2020;16:1-7.

19. Walls AC, Park YJ, Tortorici MA, Wall A, McGuire AT, Veesler D. Structure, function, and antigenicity of the SARS-CoV-2 spike glycoprotein. Cell 2020;181:281-92.
20. Yang D, Leibowitz JL. The structure and functions of Coronavirus genomic 3' and 5' ends. Virus Res 2015;206:120-33.

21. Zhang T, Wu Q, Zhang Z. Probable pangolin origin of SARS-CoV-2 associated with the COVID-19 outbreak. Curr Biol 2020;30:1346-51.

22. Andersen KG, Rambaut A, Lipkin WI, Holmes EC, Garry RF. The proximal origin of SARS-CoV-2. Nat Med 2020;26:450-2.

23. Graham RL, Baric RS. Recombination, reservoirs, and the modular spike: Mechanisms of Coronavirus cross-species transmission. J Virol 2010;84:3134-46.

24. Guo G, Ye L, Pan K, Chen Y, Xing D, Yan K, et al. New insights of emerging SARS-CoV-2: Epidemiology, etiology, clinical features, clinical treatment, and prevention. Front Cell Dev Biol 2020;8:410.

25. Smith EC, Blanc H, Surdel MC, Vignuzzi M, Denison MR Coronaviruses lacking exoribonuclease activity are susceptible to lethal mutagenesis: Evidence for proofreading and potential therapeutics. PLoS Pathog 2012;9:e1003565.

26. Viceconte G, Petrosillo N. COVID-19 R0: Magic number or conundrum? Infect Dis Rep 2020;12:8516.

27. Heffernan JM, Smith RJ, Wahl LM. Perspectives on the basic reproductive ratio. J R Soc Interface 2005;2:281-93.

28. Lan J, Ge J, Yu J, Shan S, Zhou H, Fan S, et al. Structure of the SARSCoV-2 spike receptor-binding domain bound to the ACE2 receptor. Nature 2020;581:215-20.

29. Wu Y, Wang F, Shen C, Peng W, Li D, Zhao C, et al. A noncompeting pair of human neutralizing antibodies block COVID-19 virus binding to its receptor ACE2. Science 2020;368:1274-8

30. Wang Q, Zhang Y, Wu L, Niu S, Song C, Zhang Z, et al. Structural and functional basis of SARS-CoV-2 entry by using human ACE2. Cell 2020;181:894-904

31. Chen L, Li X, Chen M, Feng Y, Xiong C. The ACE2 expression in human heart indicates new potential mechanism of heart injury among patients infected with SARS-CoV-2. Cardiovasc Res 2020;116:1097-100.

32. Alsaadi EA, Jones IM. Membrane binding proteins of coronaviruses. Future Virol 2019;14:275-86.

33. Li F. Receptor recognition mechanisms of Coronaviruses: A decade of structural studies. J Virol 2015;89:1954-64.

34. Dimitrov DS. Virus entry: Molecular mechanisms and biomedical applications. Nat Rev Microbiol 2004;2:109-22.

35. Fehr AR, Perlman S. Coronaviruses: An overview of their replication and pathogenesis. In: Maier HJ, Bickerton E, Britton P, editors. Coronaviruses: Methods and Protocols. $1^{\text {st }}$ ed., Vol. 1282. New York: Springer; 2015. p. 1-3.

36. Gao Y, Yan L, Huang Y, Liu F, Zhao Y, Cao L, et al. Structure of the RNA-dependent RNA polymerase from COVID-19 virus. Science 2020;15:779-82

37. Fantini J, di Scala C, Chahinian H, Yahi N. Structural and molecular modelling studies reveal a new mechanism of action of chloroquine and hydroxychloroquine against SARS-CoV-2 infection. Int J Antimicrob Agents 2020;55:105960.

38. Shang J, Wan Y, Luo C, Ye G, Geng Q, Auerbach A, et al. Cell entry mechanisms of SARS-CoV-2. Proc Natl Acad Sci USA 2020;117:11727-34.

39. Bi Q, Wu Y, Mei S, Ye C, Zou X, Zhang Z, et al. Epidemiology and transmission of COVID-19 in 391 cases and 1286 of their close contacts in Shenzhen, China: A retrospective cohort study. Lancet Infect Dis 2020;20:911-9.

40. Gralton J, Tovey ER, McLaws ML, Rawlinson WD. Respiratory virus RNA is detectable in airborne and droplet particles. J Med Virol 2013;85:2151-9.

41. Somsen GA, van Rijn C, Kooij S, Bem RA, Bonn D. Small droplet aerosols in poorly ventilated spaces and SARS-CoV-2 transmission. Lancet Respir Med 2020;8:658-9.

42. Goldman E. Exaggerated risk of transmission of COVID-19 by fomites. Lancet Infect Dis 2020;20:892-3.

43. Al Huraimel K, Alhosani M, Kunhabdulla S, Stietiya MH. SARSCoV-2 in the environment: Modes of transmission, early detection and potential role of pollutions. Sci Total Environ 2020;15:140946.

44. Nicola M, Alsafi Z, Sohrabi C, Kerwan A, Al-Jabir A, Iosifidis C, et al. The socio-economic implications of the Coronavirus pandemic (COVID-19): A review. Int J Surg 2020;78:185-93.

45. Chakraborty I, Maity P. COVID-19 outbreak: Migration, effects on society, global environment and prevention. Sci Total Environ 2020;728:138882.

46. Dhinakaran DD, Kesavan DN. Exports and imports stagnation in India during COVID-19-a review. Acad Leadersh Online J 2020;21:72-90.

47. Choudhari R. COVID 19 pandemic: Mental health challenges of internal migrant workers of India. Asian J Psychiatr 2020;54:102254. 
48. Donthu N, Gustafsson A. Effects of COVID-19 on business and research. J Bus Res 2020;117:284-9.

49. Fallon PR, Lucas RE. The impact of changes in job security regulations in India and Zimbabwe. World Bank Econ Rev 1991:5:395-413.

50. Anant TC, Hasan R, Mohapatra P, Nagaraj R, Sasikumar SK. Labor markets in India: issues and perspectives. In: Felipe J, Hasan R, editors. Labor Markets in Asia: Issues and Perspectives. $1^{\text {st }}$ ed. London: Palgrave Macmillan UK; 2006. p. 205-300.

51. Krishna R. Unemployment in India. Econ Polit Wkly 1973;8:475-84.

52. Lakshminarayanan S. Role of government in public health: Current scenario in India and future scope. J Family Community Med 2011;18:26-30

53. Ayati N, Saiyarsarai P, Nikfar S. Short and long term impacts of COVID-19 on the pharmaceutical sector. Daru 2020;2020:1-7.

54. Gupta M, Abdelmaksoud A, Jafferany M, Lotti T, Sadoughifar R, Goldust M. COVID-19 and economy. Dermatol Ther 2020;33:e13329.

55. Sardar T, Nadim SS, Rana S, Chattopadhyay J. Assessment of lockdown effect in some states and overall India: A predictive mathematical study on COVID-19 outbreak. Chaos Solitons Fractals 2020;139:110078.

56. CRS. Global Economic Effects of COVID-19; 2020. Available from: https://www.fas.org/sgp/crs/row/r46270.pdf. [Last accessed on 2020 Jul 22].

57. Nagaraj R. Employment and wages in manufacturing industries: Trends, hypothesis and evidence. Econ Polit Wkly 1994;29:177-86.

58. Loades ME, Chatburn E, Higson-Sweeney N, Reynolds S, Shafran R, Brigden A, et al. Rapid systematic review: The impact of social isolation and loneliness on the mental health of children and adolescents in the context of COVID-19. J Am Acad Child Adolesc Psychiatry 2020;59: 1218-39.

59. Torales J, O’Higgins M, Castaldelli-Maia JM, Ventriglio A. The outbreak of COVID-19 Coronavirus and its impact on global mental health. Int J Soc Psychiatry 2020;66:317-20.

60. Brown EE, Kumar S, Rajji TK, Pollock BG, Mulsant BH. Anticipating and mitigating the impact of COVID-19 pandemic on Alzheimer's disease and related dementias. Am J Geriatr Psychiatry 2020;28:712-21.

61. Li S, Wang Y, Xue J, Zhao N, Zhu T. The impact of COVID-19 epidemic declaration on psychological consequences: A study on active weibo users. Int J Environ Res Public Health 2020;17:2032.

62. Paital B, Das K, Parida SK. Inter nation social lockdown versus medical care against COVID-19, a mild environmental insight with special reference to India. Sci Total Environ 2020;728:138914.

63. Bera B, Bhattacharjee S, Shit PK, Sengupta N, Saha S. Significant impacts of COVID-19 lockdown on urban air pollution in Kolkata (India) and amelioration of environmental health. Environ Dev Sustain 2020;2020:1-28

64. Mahato S, Pal S, Ghosh KG. Effect of lockdown amid COVID-19 pandemic on air quality of the megacity Delhi, India. Sci Total Environ 2020;730:139086
65. Gautam S. The influence of COVID-19 on air quality in India: A boon or inutile. Bull Environ Contam Toxicol 2020;104:724-6.

66. Kumar S. Effect of meteorological parameters on spread of COVID-19 in India and air quality during lockdown. Sci Total Environ 2020;745:141021

67. Lokhandwala S, Gautam P. Indirect impact of COVID-19 on environment: A brief study in Indian context. Environ Res 2020;188:109807.

68. Taghrir MH, Akbarialiabad H, Marzaleh MA. Efficacy of mass quarantine as leverage of health system governance during COVID-19 outbreak: A Mini policy review. Arch Iran Med 2020;23:265-7.

69. Ma SM, Hassan S. Assess the awareness and attitude regarding prevention of Coronavirus disease 2019. Asian J Pharm Clin Res 2020;13:95-8.

70. Kumar SU, Kumar DT, Christopher BP, Doss CGP. The rise and impact of COVID-19 in India. Front Med (Lausanne) 2020;7:250.

71. Dong ZQ, Ma J, Hao YN, Shen XL, Liu F, Gao Y, et al. The social psychological impact of the COVID-19 pandemic on medical staff in China: A cross-sectional study. Eur Psychiatry 2020;63:e65-72.

72. Krishnakumar B, Rana S. COVID 19 in INDIA: Strategies to combat from combination threat of life and livelihood. J Microbiol Immunol Infect 2020;53:389-91

73. Temsah MH, Al-Sohime F, Alamro N, Al-Eyadhy A, Al-Hasan K, Jamal A, et al. The psychological impact of COVID-19 pandemic on health care workers in a MERS-CoV endemic country. J Infect Public Health 2020;13:877-82.

74. Maiti R, Bhatia V, Padhy BM, Hota D. Essential medicines: An Indian perspective. Indian J Community Med 2015;40:223-32.

75. Ahmad A, Patel I, Parimilakrishnan S, Mohanta GP, Chung H, Chang J. The role of pharmacoeconomics in current Indian healthcare system. J Res Pharm Pract 2013;2:3-9.

76. Bukhari N, Rasheed H, Nayyer B, Babar Z. Pharmacists at the frontline beating the COVID-19 pandemic. J Pharm Policy Pract 2020;13:8.

77. Alvi M, Gupta M. Learning in times of lockdown: How Covid-19 is affecting education and food security in India. Food Secur 2020;2020:1-4.

78. Dhawan S. Online learning: A panacea in the time of COVID-19 crisis. J Educ Technol Syst 2020;49:5-22.

79. Kapasia N, Paul P, Roy A, Saha J, Zaveri A, Mallick R, et al. Impact of lockdown on learning status of undergraduate and postgraduate students during COVID-19 pandemic in West Bengal, India. Child Youth Serv Rev 2020;116:105194.

80. Patil A, Rajadhyaksha V. Evolving role of pharmaceutical physicians in the industry: Indian perspective. Perspect Clin Res 2012;3:35-9.

81. Jena PK. Impact of pandemic COVID-19 on education in India. Purakala 2020;31:142-9.

82. Imielski B. The detrimental effect of COVID-19 on subspecialty medical education. Surgery 2020;168:218-9. 